\title{
ASSESSMENT TOOL FOR ENVIRONMENTAL MANAGEMENT SYSTEM PERFORMANCE ACCORDING TO THE ISO 14001
}

\author{
Mohammed HADINI, Mohamed Ben Ali, Said Rifai, \\ Otmane Bouksour and Ahmed Adri
}

LMPGI Research Laboratory, ESTC High School of Technology, and ENSEM School of Engineering, University Hassan II of Casablanca, Morocco

\begin{abstract}
The present paper is concerned with a statistical approach involving latent and manifest variables applied in order to assess the Environmental Management System performance. The main idea is to develop an assessment tool in order to measure the Environmental Management System practices performances (which are divided into seven segments: Context of the organization, Leadership, Planning, Improvement, Support, Operation, and Performance Evaluation) described in the ISO14001 standard. , enabling the company to characterize her performance regarding to the ISO 14001 standards. For this, we conceptualize a structural equation modeling (SEM) which describes various causal connections between the Environmental Management requirements. The SEM's resolution is based on the Partial Least squares (PLS) method and the implementation is running in the XLSTAT software. The obtained results could be examined in order to plan the improvements and develop an action plan. It is necessary to control Environmental Management System performance to ensure that it is either good enough, or that something is being done to improve it.
\end{abstract}

Keywords: Environmental Management System Performance; ISO 14001; Modeling approach; PLS; Company

Cite this Article: Mohammed HADINI, Mohamed Ben Ali, Said Rifai, Otmane Bouksour and Ahmed Adri, Assessment Tool for Environmental Management System Performance According to the ISO 14001, International Journal of Management, 10 (5), 2019, pp. 73-83.

http://iaeme.com/Home/issue/IJM?Volume=10\&Issue=5

\section{INTRODUCTION}

Factories, and more generally companies, are worried about the impact of their activity on the environment. Their reality invites them to meet a threefold challenge: to limit the consequences of their daily production, to prevent the risks related to an abnormal situation, and eventually, to reduce non-renewable natural resources consumption. 
The protection of the natural environment is increasingly an important concern in the management of companies. With the advent of ISO 14001 standards, companies' interest in environmental management has increased.

The ISO 14001 standard reveals a global consensus on the important requirements that an environmental management system must have to ensure the effective functioning of an organization, regardless of its size, type, location or level of maturity. All components of the ISO 14001 standard are mandatory, but the requirements specify which elements of an environmental management system must be covered, and the ISO 14001 does not define how to achieve these requirements. The impact of ISO certification is to some extent not analyzed enough in light of the considerable human, financial and organizational investments made by organizations to meet the requirements of this standard. For this, Environment Management is considered as a dynamic and complex concept connecting various latent elements that should be measured by observed variables.

In the present paper, our objective is presenting a SEM using PLS approach, which enables a company to measure its environment Management system performance index as the result of the environment practices (which divided into seven segments: Context of the organization ,Leadership, Planning, improvement, support , operation, and performance evaluation) described in the ISO14001 standard.

Through a globalist and interdependent approach, the objective is to build a performance index based on the evaluation of five dimensions: Leadership index, Planning index, improvement index, support index, operation index, and performance evaluation index.

\section{ABOUT STRUCTURAL EQUATION MODELLING}

The Structural Equation Modelling (SEM) is a method to define complex interacting systems [1] and it allows studying the causal connections between multiple latent variables. These variables represent a concept but we can only measure them with manifest variables (MV) [2]. MES is used for the generalization of many classic models such as principal components analysis, factor analysis, and canonical analysis. These statistical models are used in several research fields [3], [4] especially in the marketing field to construct satisfaction indicators [5]. This type of modeling is thus important to test the hypotheses of our conceptual model. There are two methods of modeling via (MES) for estimating the existing relationships between the constructs: partial least square (PLS), based on PLS variances, and linear structural relationship (LISREL), based on maximum likelihood the LISREL method and the PLS method [6], [7].

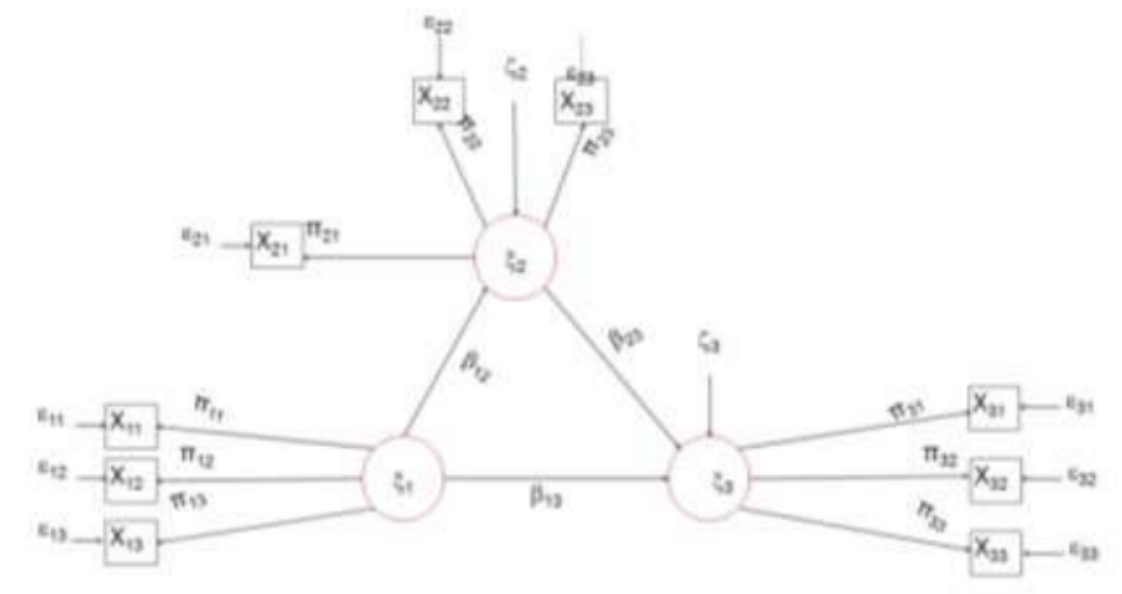

Figure 1 Example of path diagram where $\xi_{i}$ : Latent variable, $X_{i j}$ : Manifest variable 
The path diagram is composed from two connected sub models, the structural and the measurement models. Structural model shows the different causal connections between latent variables through structural coefficients $\beta_{i j} ;\left(\beta_{i j}\right.$ represents the connection from $\xi_{i}$ to $\left.\xi\right)$. As for the measurement model, each latent variable $\xi_{i}$ is explained by several manifest variable $\mathrm{X}_{\mathrm{ij}}$ through outer coefficient $\pi_{\mathrm{ij}}$. The outer and significantly impacted by the decisions and actions of the structural coefficients are computed using multiple linear regression techniques. The purpose of the SEM approach is to test the postulated causal relationship and the structural model's goodness of fit. There are two approaches for estimating SEM, which are the best known: The Linear Structural Relations method (LISREL) and the PLS.

- The PLS method is a regression analysis method of latent variables with their indicators and latent variables among them-selves, the PLS method evaluates the latent variables as linear combinations of the manifest ones; it estimates simultaneously the weights (inner and outer coefficients) associated to the SEM Model. These weights are calculated in a way that maximize the model's goodness of fit, and thus the ability to explain the ultimate endogenous latent variable. It was developed by Herman Wold [8] and mainly used for the analysis of small samples (observations) and several variables. It became operational with the development of PLS 1.8 software [1]. This method, which is based on the calculation of single and multiple regressions, requires few hypotheses.

- The Linear Structural Relations method (LISREL) was developed by Jöreskog (1967). The latter has developed LISREL reference software [9]. This method is based on maximum likelihood. It is considered to be a demanding approach in terms of probabilistic assumptions. It requires the independence of observations and the multivariate normality of the data.

We have chosen for our exploratory research the PLS approach because it is adapted to the development of theories and prediction, and to predictive causal analyses in complex situations and with weak theoretical information[10] .Several software's have been developed to operationalize the PLS approach such as PLSGRAPH, LVPLS, SMARTPLS, and XLSTAT that we have chosen to analyze the data from our survey.

\section{HEALTH AND SAFETY PRACTICES}

\subsection{Environment concepts}

The maturity of companies has considerably improved during the last years, although at all times, considerations were made via-à-vis the interactions between the workers' health status and the environment in which they operate.

Factories, and more generally companies, are worried about the impact of their activity on the environment. Their reality invites them to meet a threefold challenge: to limit the consequences of their daily production, to prevent the risks related to an abnormal situation, and eventually, to reduce non-renewable natural resources consumption.

Natural and ecological resources are a source of wealth, the degradation of which can be a constraint to human and economic development. Awareness is high among officials, economic operators and the general population to remedy the severe degradation of natural resources caused by pollution, and companies today are showing a strong political will to cooperate to protect and manage the environment.

Industrial development can only be achieved through a parallel development of environmental awareness. Since environmental problems cross borders, this creates the need for legislation and standards that are globally uniform to prevent opportunists from making profits at the expense of the environment.

The ISO 14001 standard defines the requirements for environmental management systems (Figure 1\&2), and remains globally relevant for organizations wishing to operate in an environmentally sustainable manner. 
The first objective of the ISO 14001 standard is to propose an organizational concept to deploy the environmental strategy at all levels of the company and to make it sustainable. It is essential to keep in mind that environmental protection and pollution prevention objectives must not compromise the company's socio-economic needs in its local and global context.

The protection of the natural environment is increasingly an important concern in the management of companies. With the advent of ISO 14001 standards, companies' interest in environmental management has increased.

According to the ISO 14001 There are many reasons why an organization should take a strategic approach to improving its environmental performance. The ISO 14001 helps [11]:

- Demonstrate compliance with current and future statutory and regulatory requirements ,

- Increase leadership involvement and engagement of employees,

- Improve company reputation and the confidence of stakeholders through strategic communication,

- Achieve strategic business aims by incorporating environmental issues into business management,

- Provide a competitive and financial advantage through improved efficiencies and reduced costs,

- Encourage better environmental performance of suppliers by integrating them into the organization's business systems.

The decision to implement the Environmental Management System depends largely on the responsibility of the top management.

The ISO 14001 standard reveals a global consensus on the important requirements that an environmental management system must have to ensure the effective functioning of an organization, regardless of its size, type, location or level of maturity. All components of the ISO 14001 standard are mandatory, but the requirements specify which elements of an environmental management system must be covered, and the ISO 14001 does not define how to achieve these requirements.

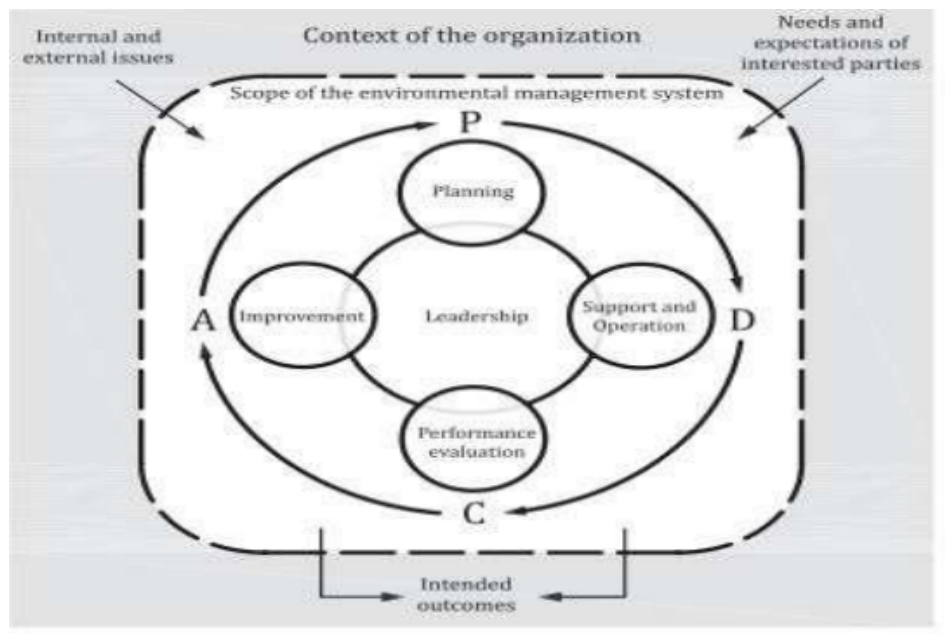

Figure 2 Relationship between PDCA and the framework in this International Standard [12]

In the present paper, our objective is presenting a SEM using PLS approach, which enables a company to measure its environment Management system performance index as the result of the environment practices (which divided into seven segments: Context of the organization ,Leadership, Planning, Improvement, Support , Operation, and Performance Evaluation) described in the ISO14001 standard

The following table illustrates the clause structure of ISO 14001:2015 in more detail and in the context of the PDCA cycle - starting at clause 4 (the first clause specifying a requirement). 


\begin{tabular}{|c|c|c|c|c|c|c|}
\hline $\begin{array}{l}\text { 4. Context of the } \\
\text { organization }\end{array}$ & 5. Leadership & 6. Planning & 7. Support & 8. Operation & $\begin{array}{l}\text { 9. Performance } \\
\text { evaluation }\end{array}$ & 10. Improvement \\
\hline $\begin{array}{l}4.1 \text { Understanding } \\
\text { the organization } \\
\text { and its context }\end{array}$ & $\begin{array}{l}5.1 \text { Leadership and } \\
\text { commitment }\end{array}$ & $\begin{array}{l}6.1 \text { Actions to } \\
\text { address risk } \\
\text { associated with } \\
\text { threats and } \\
\text { opportunities }\end{array}$ & 7.1 Resources & $\begin{array}{l}8.1 \text { Operational } \\
\text { planning and } \\
\text { control }\end{array}$ & $\begin{array}{l}9.1 \text { Monitoring. } \\
\text { measurement, } \\
\text { analysis and } \\
\text { evaluation }\end{array}$ & 10.1 General \\
\hline $\begin{array}{l}4.2 \text { Understanding } \\
\text { the needs and } \\
\text { expectations of } \\
\text { interested parties }\end{array}$ & $\begin{array}{l}5.2 \text { Environmental } \\
\text { policy }\end{array}$ & $\begin{array}{l}6.2 \text { Environmental } \\
\text { objectives and } \\
\text { planning to achieve } \\
\text { them }\end{array}$ & 7.2 Competence & $\begin{array}{l}8.2 \text { Emergency } \\
\text { preparedness and } \\
\text { response }\end{array}$ & 9.2 Internal audit & $\begin{array}{l}10.2 \text { Nonconformity } \\
\text { and corrective } \\
\text { action }\end{array}$ \\
\hline $\begin{array}{l}\text { 4.3 Determining the } \\
\text { scope of the EMS }\end{array}$ & $\begin{array}{l}5.3 \text { Organizational } \\
\text { roles, } \\
\text { responsibilities and } \\
\text { authorities }\end{array}$ & & 7.3 Awareness & & $\begin{array}{l}\text { 9.3 Management } \\
\text { review }\end{array}$ & $\begin{array}{l}10.3 \text { Continual } \\
\text { improvement }\end{array}$ \\
\hline \multirow{2}{*}{$\begin{array}{l}4.4 \text { Environmental } \\
\text { management } \\
\text { system }\end{array}$} & & & 7.4 Communication & & & \\
\hline & & & $\begin{array}{l}7.5 \text { Documented } \\
\text { information }\end{array}$ & & & \\
\hline
\end{tabular}

Figure 3 The clause structure of ISO 14001:2015 [13]

\section{PRESENTATION OF THE RESEARCH MODEL}

Our model relies on 8 criteria which are divided into 2 families: 7 criteria refer to the means (Context of the organization, Leadership, Planning, improvement, support, operation, and performance evaluation). The one other criteria refer to the performance index results (Figure.3). Criteria for the used means show how the organization works, and whether these tools help attain the expected goals. The criteria related to results take into consideration what the company has attained with regard to the different stakeholders. They show whether there are global measures that demonstrate the effectiveness of the work and whether the strategic goals have been attained. There are causal relations between the criteria of means and the criteria of results. In other words, the means in place are the causes of the given results.

It should be noted that for each causal relationship, a derived hypothesis has been formulated. Since the proposed conceptual model has 12 causal relationships, 12 derived hypotheses have been formulated. 


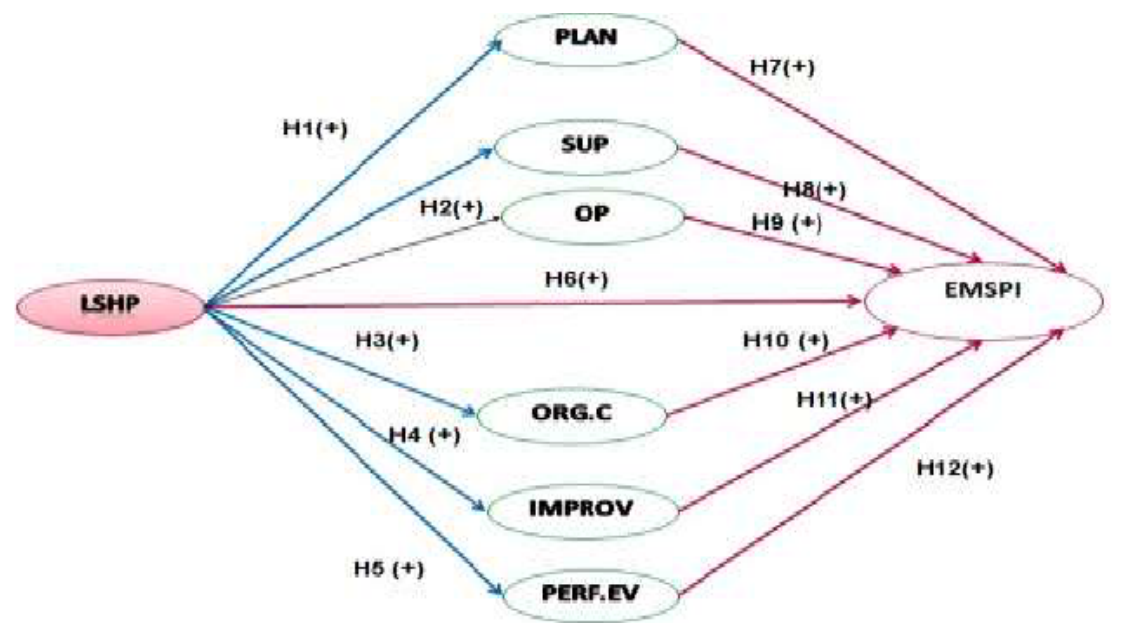

Figure 4 The Proposed Model

Table 1 Showing the codes used in the causal model

\begin{tabular}{|c|c|l|}
\hline $\begin{array}{c}\text { CONSTRUCTS OF } \\
\text { THE PROPOSED } \\
\text { MODEL }\end{array}$ & CODE & \multicolumn{1}{|c|}{ TITLE } \\
\hline \multirow{4}{*}{ Environment Practices } & ORG.C & Context of the organization \\
\cline { 2 - 3 } & LSHP & Leadership \\
\cline { 2 - 3 } & PLAN & Planning \\
\cline { 2 - 3 } & IMPROV & Improvement \\
\cline { 2 - 3 } & SUP & Support \\
\cline { 2 - 3 } & OP & Operation \\
\cline { 2 - 3 } & PREF.EV & Performance Evaluation \\
\hline \multirow{2}{*}{ Criteria results (goals) } & EMSPI & $\begin{array}{l}\text { Environment Management } \\
\text { system Performance index }\end{array}$ \\
\hline
\end{tabular}

\section{RESEARCH METHODOLOGICAL FRAMEWORK}

\subsection{Methodology Adopted}

Manifest variables have a fundamental role to measure the Environment Management System performance; they are a basic input of the SEM model and considered as indicators of the latent variables. More precisely, the manifest variables are the scores given by respondents as part of the questionnaire survey. Moreover, we assume some standard statistical hypotheses related to SEM ([14],[15]:

- The manifest variables are independent

- Respondents sampling is random and representative

- The minimum sample size required is between 30 and 100

- All the relationships are linear (Multilinear Regression)

- Multivariate Normality of distribution

- No flattening and no asymmetry

- An Appropriate scale interval is defined (from 1 to 10) for all the respondents" scores.

We have developed a questionnaire survey intended for a sample respondents considered by the organization as a representative sampling. Each latent variable is associated with a series of questions to measure the degree of relevance about the core subject. Figure 5 illustrates our methodology. 


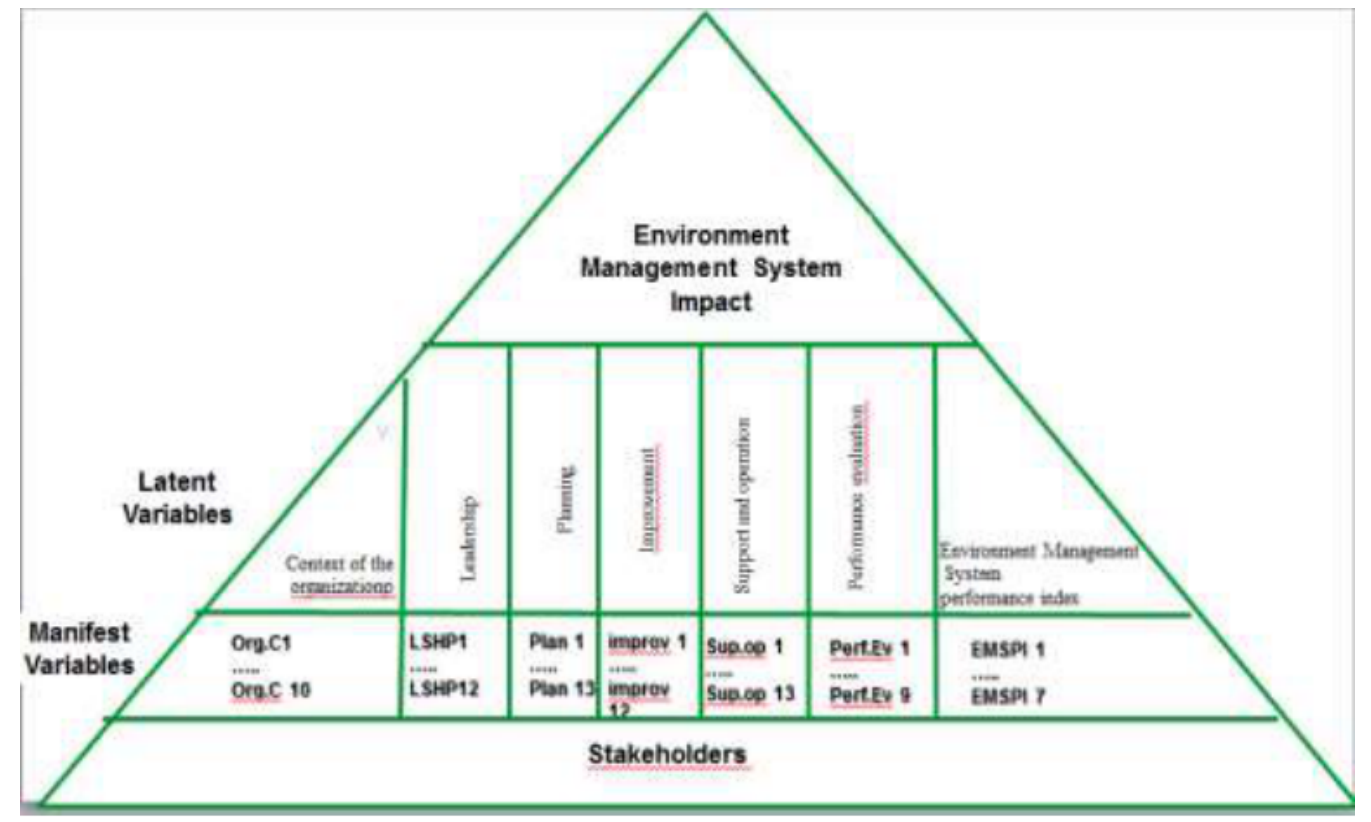

Figure 5 Methodology Adopted

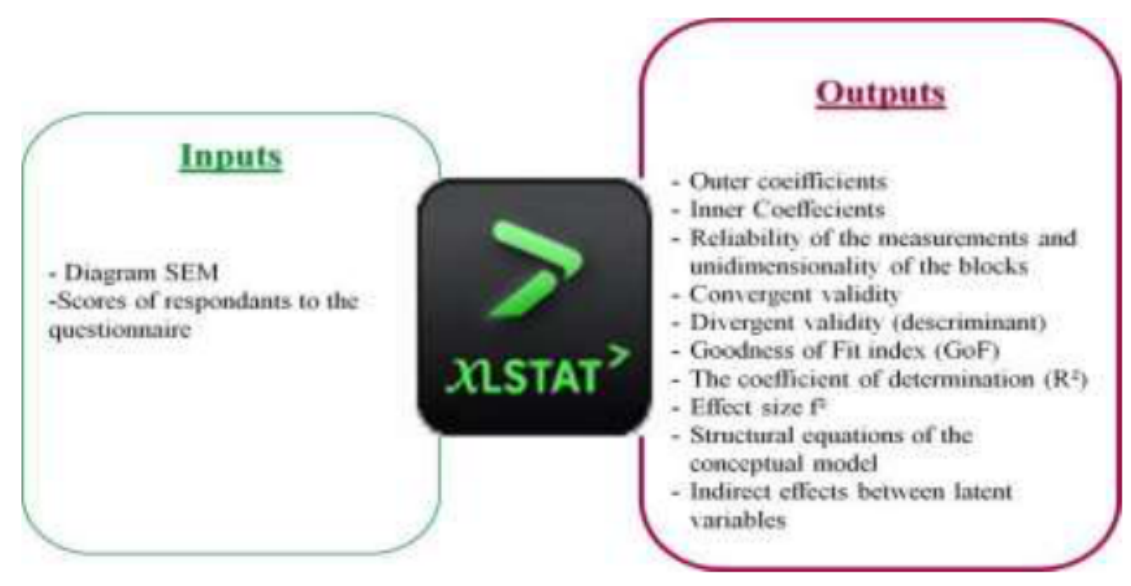

Figure 6 Inputs and Outputs of the XLSTAT software

\subsection{Sampling}

As mentioned before, we have developed a questionnaire survey intended for a sample respondents considered by the organization as a representative sampling. Each latent variable is associated with a series of questions to measure the degree of relevance about the core subject.

\subsection{Evaluation of the proposed model}

The evaluation of a PLS model requires careful consideration of three main methodological elements [16], the evaluation of the reliability and validity of the internal and external subparts of the overall model.

Reliability analysis of the scales and unidimensionality control were made before starting to test the internal and external validity of the conceptual model. 


\subsection{Reliability of measurements}

To ensure the reliability of the measurements we will use Chronbach's alpha index. This index makes it possible to study the internal consistency between the set of items for each latent variable, i.e., it measures the reliability of measures of a set of questions (or items) designed to measure a specific phenomenon (responses to questions on the same subject must be correlated so that all respondents or respondents must understand each question in the same way).For each dimension, the value of this internal consistency is greater than 0.8 , which shows the good level of reliability, and this, following the recommendations of Nunnally and Bernstein [17].

The Chronbach alpha $(\alpha)$ is expressed:

$\underline{k}$ : Number of items;

$$
\alpha=\frac{k \times \bar{R}_{m}}{1+(k-1) \times \bar{R}_{m}}
$$

$\bar{R}_{m}$ : Mean correlation between all item pairs

\subsection{Evaluation of the measurement model}

The evaluation of the external model is carried out by ensuring that the validity is convergent and divergent. If these two conditions are met, the measurement model is valid.

\subsubsection{Convergent validity}

The objective of this test is to ensure that each item shares more variances with its construct (latent variable) than with its measurement error. To do this, analyses of factor contributions, the average variance extracted for each manifest variable and cross-laodings will be examined.

\subsubsection{Divergent validity (descriminant)}

Discriminant validity is tested according to the recommendations of Chin [18]. To assess the said validity, the square root of the average extracted variance (AVE) for each factor (Latent Variable) shall be compared with the correlation between the two-by-two factors. If the AVE square root is greater than the correlations between the factors, divergent validity is ensured. This validity is acquired if the manifest variables share more variances with their latent variables than with others. In other words, items measuring a phenomenon must be weakly correlated with items measuring other constructs (Latent Variables).

This indicator is calculated as follows [19]:

$$
\boldsymbol{A} \boldsymbol{V} \boldsymbol{E}=\frac{\sum\left[\gamma_{i}^{2}\right] \operatorname{var}(V L)}{\sum\left[\gamma_{i}^{2}\right] \operatorname{var}(V L)+\sum\left[\operatorname{var}\left(\varepsilon_{i}\right)\right]}
$$

With $\gamma_{i}$ : factorial contributions of manifest variables associated with a Latent Variable (VL); var : Variance ; $\boldsymbol{\varepsilon}_{\boldsymbol{i}}$ : Terms of errors related to each manifest variable; VL : Latent Variable

\subsection{Validation of the structurel model}

\subsubsection{The coefficient of determination $\left(\mathrm{R}^{2}\right)$}

The coefficient of determination $\left(\mathrm{R}^{2}\right)$ is an indicator for judging the quality of a linear, single or multiple regression. This index has a value between 0 and 1, it measures the adequacy between the model and the observed data. The structural model is retained when $\mathrm{R}^{2}>0.67$ [20].

$$
R^{2}=1-\frac{S C R}{S C T}=1-\frac{\sum_{i=1}^{n}\left(y_{i}-\hat{y}_{i}\right)^{2}}{\sum_{i=1}^{n}\left(y_{i}-\bar{y}\right)^{2}}=\frac{\sum_{i=1}^{n}\left(\hat{y}_{i}-\bar{y}\right)^{2}}{\sum_{i=1}^{n}\left(y_{i}-\bar{y}\right)^{2}}
$$


with :

$\mathrm{SCR}$ is the sum of the squares of the residues (Residual variance)

$\mathrm{SCT}$ is the sum of the total squares (Total variance explained)

$y_{i}$ measurement values

$\hat{\mathrm{y}}_{i}$ the predicted values

$\overline{\mathrm{y}}$ the average of the measurements

\subsubsection{Goodness of Fit index (GoF)}

This index is defined by the geometric mean of the communities mean (or AVE) on the set of latent variables $\left(\bar{H}^{-} 2\right)$ and the mean of the coefficients of determinations $\left(\mathrm{R}^{2}\right)$ associated with endogenous latent variables: $:\left(\bar{R}_{\mathrm{R}}^{2}\right): \mathrm{GoF}=\left(\sqrt{\overline{\mathrm{H}} 2 \times \mathrm{R}^{-2}}\right)$. According to Wetzels et al. [21], the usual values of this index are $0.1,0.25$ and 0.36 . They refer respectively to a small, medium and large adequacy of the model.

\subsubsection{Effect size $\left(\mathrm{f}^{2}\right)$}

This index allows us to ensure the validity and magnitude of structural coefficients. It would be fair to note that the usual values of $\mathrm{f}^{2}=\frac{R^{2} \text { incl }-R^{2} \text { excl }}{1-R^{2} \text { incl }}$ are $0.02,0.15$ and 0.35 . The said values refer respectively to small, medium and large effects [22].

\subsection{Environment system performance Index}

Inspired by the work of Fornel [23], about the American customer satisfaction index, we can compute an index I corresponding to each core subject and the Environmental Management System performance Index, by [23] [15]:

Where

$$
I=\frac{\sum_{i=1}^{n} w_{i} \overline{x_{i}}-\sum_{i=1}^{n} w_{i}}{(\mathrm{~N}-1) \sum_{i=1}^{n} w_{i}} \times 100
$$

xi : Arithmetic average of manifest variables,

$\mathrm{n}$ : Number of manifest variables, wi : Outer coefficient (weight), Number of manifest variables, wi : Outer coefficient (weight), performance is measured by the EMSPI such that:

$0 \% \leq E M S P I \leq 100 \%$

\section{DISCUSSION AND CONCLUSION}

The present work developed a SEM with the objective to assess the Environmental Management System performance, regarding the guidelines of the ISO 14001. Based on the principles and considerations of this norm, we present an Environmental Management System model enabling a company to evaluate its Environmental Management performance commitment and actions.

Once the model is stated, our next step is to run its implementation for a multinational energy company, by using the XLSTAT Software.

\section{REFERENCES}

[1] Fernandes, V, En Quoi L'approche PLS Est-Elle Une Méthode a (Re)-Découvrir Pour Les Chercheurs En Management?\| Management 15 (1): 2012, pp 102. 
[2] Roussel, P., F. Durrieu, E. Campoy, and A. El Akremi, Méthodes D'équations Structurelles: Recherches et Applications En Gestion. Paris: Economica, 2002

[3] Jacobowicz, E. ='Contributions aux modeles d'equations structurelles a variables Latentes", These de Doctorat, Conservatoire national des arts et metiers de Paris, 2007.

[4] Elhasbi,A, Barkaoui,M, Bouksour,O and Kamach,O , The territorial attractiveness for foreign investments of Mediterranean cities: the case of city of Tangier, International Journal of Euro-Mediterranean Studies Table of Contents, volume9 number2 2016 pp3-26

[5] Clémence, D, Une Méthode Alternative L'approche PLS: Comparaison et Application Aux Modèles Conceptuels Marketings. - Statistique Aplliquée 52 (3), 2004, pp 37-72.

[6] Lacroux, A, L'analyse Des Modèles de Relations Structurelles Par La Méthode PLS: Une Approche Émergente Dans La Recherche Quantitative En GRH.\|l Paper presented on XXème Congres (AGRH), Toulouse, November 2009, pp 17-21

[7] Benali, M. Rifai, S. Bouksour, O, Barrijal, S. Young manufacturing enterprises in the growth phase located in the Wilaya of Tetouan, Morocco: A model for measurement of the impact of quality on their growth, ASIAN JOURNAL OF MANAGEMENT RESEARCH, Volume 6 Issue 1, 2015, pp 208-222

[8] Tenenhaus, M. —L'approche PLS.” Rev. Stat. Appliquée 2, 1999, pp 5-40.

[9] Joreskog, G. and Sorbom,D. A. G.. - Recent Developments in Structural Equation Modeling\|: Journal of Marketing Research, Special Issue on Causal Modeling, Vol. 19, No. 4, pp. 404-416, 1982.

[10] Zaied, Y. B., and S. A. Ramzi, Les Déterminants Du Succès Entrepreneurial: Une Étude Empirique de La Région de Sfax En Tunisie.l Accessed October 15, 2016. https://ideas.repec.org/p/tut/cremwp/201235.html,2012

[11] https://www.iso.org/files/live/sites/isoorg/files/archive/pdf/en/iso_14001__key_benefits_fr.pdf

[12] ISO/FDIS 14001:2015(E). Environmental management systems — Requirements with guidance for use. $\mathrm{p} 7$

[13] [xx2] Qudos Management Pty. Ltd., Article - February 2015.

[14] Kanji, G. K. and Wallace, W. Business excellence through customer satisfaction,॥ Total Qual. Manag., vol. 11, no. 7, pp. 979-998, 2000.

[15] Fethallah, W. Chraibi, L., Sefiani, N.: Assessment Tool for Social Responsibility Performance According to the ISO 26000, World Academy of Science, Engineering and Technology International Journal of Industrial and Manufacturing Engineering Vol:10, No:10, (2016)

[16] Hulland, J. ='Use of partial least squares (PLS) in strategic management research: a review of four recent studies“", Strategic Management Journal, vol.20, N², 195-204, 1999.

[17] Nunnally, J. C. and Bernstein, I. H. Psychometric theory, (3eme Edition.) McGraw-Hill, New York, 1994 
[18] Chin W.W, How to write up and report PLS analyses, dans Esposito Vinzi, V., Chin W.W., Henseler J. et Wang H., Handbook of partial least squares, concepts, methods and applications, Springer, Heidelberg, 2012, pp 655-690.

[19] Fornell, D.F. Larcker, C. ='Evaluating structural equation models with unobservable variables and measurement error" ", Journal of Marketing Research, Vol.18, N 1 , pp.39-50, 1981.

[20] Chin, W. 'the partial least squares approach for structural equation modeling. In G. A. Marcoulides (Ed.)", Modern methods for business research, London: Lawrence Erlbaum Associates, 1998, pp. 295-236

[21] Wetzels, M. Odekerken-Schroder ,G. and Vanopen, C. =Using PLS Path Modeling for Assessing Hierarchical Construct Models: Guidelines and Empirical Illustration", MIS quarterly, Vol.33, $\mathrm{N}^{\circ} 1$, pp. 177-195, 2009

[22] Cohen, J. Statistical power analysis for the Behavioral sciences (2eedition).Hillsdale, New Jersey : Lawrence Erlbaum Associates, 1988.

[23] Fornell,C., Johnson, M. and Anderson, E. - The American customer satisfaction index: nature, purpose, and findings, $\|$ J. Mark., vol. 60, no. October, pp. 7-18, 1996.

[24] M. Satish Kumar, M.V. Raju, M. Balaji, Bachina Harish Babu, An Experimental Approach of Environmental Management Plan for Designing Asbestos Cement Pipes - A Model Study, International Journal of Mechanical Engineering and Technology 8(9), 2017, pp. $363-368$.

[25] Ismail Rumadan, Authority And Role of Local Governments On Environmental Management: A Study of Implementation of Oil and Gas Investment In Indonesia, International Journal of Civil Engineering and Technology, 9(5), 2018, pp. 1102-1110.

[26] Hasan Yousef El- Mousawi and Abdulrazzak Charbaji. Attitude of Lebanese Managers towards ISO 14001- Environmental Management System and ISO 14051 - Material Flow Cost Accounting. International Journal of Management, 7(2), 2016, pp. 224-235. 